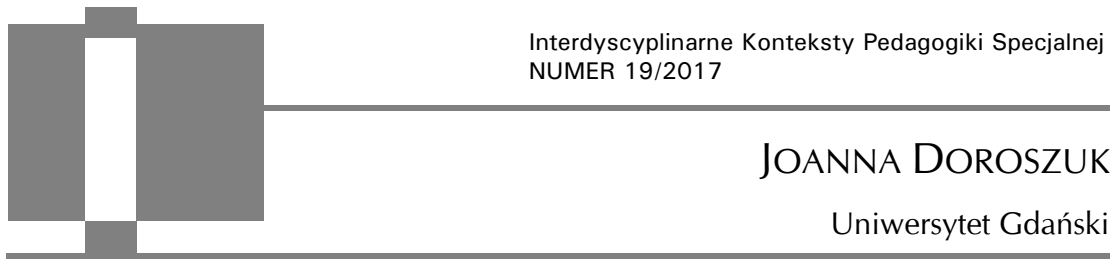

\title{
Kryzys rodziców dziecka z niepełnosprawnością w perspektywie nowych narzędzi normalizacyjnych
}

\begin{abstract}
Joanna Doroszuk, Kryzys rodziców dziecka z niepetnosprawnością w perspektywie nowych narzedzi normalizacyjnych [Crisis of parent of a child with disability in perspective of new normalization tools]. Interdyscyplinarne Konteksty Pedagogiki Specjalnej, nr 19, Poznań 2017. Pp. 51-67. Adam Mickiewicz University Press. ISSN 2300-391X

Social and cultural transformations determine functioning of disabled child's family. Internet, support groups or associations are the new normalization tools parents can use. They can affect both the construction of his or her parenting and coping in difficult situations. The author analyzes the social and emotional situation of parents of children with disabilities based on her research. Describes significant categories and areas important for further scientific exploration.
\end{abstract}

KEY WORDS: family system, child with disability

\section{Wprowadzenie}

Poznanie specyfiki funkcjonowania rodziny dziecka $\mathrm{z}$ niepełnoprawnością stanowi temat ważny zarówno $\mathrm{w}$ perspektywie holistycznego wspierania rozwoju dziecka, jak i w obszarach rozważań nad integracją osób niepełnosprawnych oraz normalizacją środowiska społecznego. Dokonujące się przemiany społeczne i kulturowe 
oraz przekształcenia paradygmatyczne $\mathrm{w}$ pedagogice specjalnej ${ }^{1}$ sprawiają, iż rodzina, jako najbliższe otoczenie człowieka niepełnosprawnego, również ulega wpływom. Zmieniając się i przeobrażając, tworzy zaś tym samym nowe obszary naukowej eksploracji. Niepełnosprawność dziecka wpływa na konstruowanie się nowej jakości funkcjonowania rodziny. Dlatego też poznanie procesu radzenia sobie z kryzysem emocjonalnym spowodowanym niepełnosprawnością dziecka, a także konstruowania się tożsamości rodzica, ma kluczowe znaczenie zarówno $\mathrm{z}$ perspektywy oferowanego rodzinie wsparcia, jak i społecznie nadawanych rodzinie dziecka $\mathrm{z}$ niepełnosprawnością znaczeń. Wieloletnia praktyka w obszarze współpracy z rodzicami, a także analiza literatury tematu oraz prowadzone przeze mnie badania naukowe dotyczące funkcjonowania rodziny dziecka $\mathrm{z}$ niepełnosprawnością, uzmysłowiły mi, jak niebagatelne znaczenie dla relacji rodzica $\mathrm{z}$ dzieckiem, terapeutą, a także otoczeniem społecznym ma właśnie poradzenie sobie przez rodzica z kryzysem emocjonalnym.

\section{Badania własne}

Rozważań dotyczących kryzysu rodziców po otrzymaniu diagnozy niepełnosprawności dziecka chciałabym dokonać w oparciu o dwa moje badania:

- badanie netnograficzne dotyczące społecznego funkcjonowania rodziny dziecka $\mathrm{z}$ niepełnosprawnością intelektualną prowadzone $\mathrm{w}$ ramach rekonstrukcji problemowej badań Haliny Borzyszkowskiej;

- badanie pilotażowe dotyczące radzenia sobie rodziców z kryzysem emocjonalnym, będącym następstwem diagnozy niepełnosprawności dziecka - wywiadów z 20 rodzicami dzieci z niepełnosprawnością objętych wczesnym wspomaganiem w rozwoju.

${ }^{1}$ Por.: A. Krause, Wspótczesne paradygmaty pedagogiki specjalnej, Oficyna Wydawnicza „Impuls”, Kraków 2011. 
Pierwsze z nich, dotyczące społecznego funkcjonowania rodziny dziecka z niepełnosprawnością, stanowiło inspirację do zgłębienia wskazanego tematu. Badanie stanowiło element znaczący przeprowadzanej przeze mnie rekonstrukcji problemowej badania H. Borzyszkowskiej dotyczącego izolacji społecznej rodzin dzieci z niepełnosprawnością intelektualną ${ }^{2}$. W badaniu zastosowano netnografię oraz analizę materiałów wizualnych. Grupę badawczą stanowiło jedno forum oraz sześć blogów prowadzonych przez rodziców dzieci z niepełnosprawnością intelektualną. Badanie miało charakter jakościowy, analiza została przeprowadzona w paradygmacie konstruktywistycznym. Wnioski z niej płynące nie mają więc charakteru uogólnień. Wskazują jednak pewne tendencje i możliwości, które mogą naznaczać funkcjonowanie współczesnych rodzin dzieci z niepełnosprawnością. Znaczącą kategorią, która pojawiła się podczas analizy materiału badawczego, były właśnie nowe narzędzia normalizacyjne. Pod pojęciem tym rozumiem możliwości, które wykorzystywali badani w opracowanych przez nich strategiach radzenia sobie. Są to m.in. korzystanie z internetu, współpraca ze stowarzyszeniami i fundacjami, powszechny dostęp do pomocy psychologicznej i terapeutycznej. Zdając sobie sprawę, iż opisywane badanie dotyczy grupy specyficznej - rodziców aktywnych w internecie, wnioskuję, iż wskazane możliwości stanowią narzędzia normalizacyjne oddziaływujące na sytuację społeczno-emocjonalną rodzin dzieci z niepełnosprawnością, z których rodzice mogą korzystać.

Sytuacja społeczno-emocjonalna rodziny jawi się w perspektywie moich badań oraz analiz jako następstwo radzenia sobie ze stresem oraz z trudnościami (kryzysami) implikowanymi, najogólniej rzecz ujmując, przez niepełnosprawność dziecka. Właśnie w tym obszarze wzrasta znaczenie nowych narzędzi normalizacyjnych, które mogą mieć znaczenie dla wypracowywanych przez rodziców strategii radzenia sobie. Przykładowo internet jako źródło

2 Por.: H. Borzyszkowska, Izolacja społeczna rodzin majacych dziecko upośledzone umystowo w stopniu lekkim, Wydawnictwo Uniwersytetu Gdańskiego, Gdańsk 1997. 
wiedzy ułatwia rodzicom odnajdywanie informacji zarówno o trudnościach, chorobach oraz o możliwościach poszukiwania wsparcia. Ma to znaczenie dla pokonywania przez rodziców problemów, a także sprawia, iż czują się oni kompetentniejsi np. $\mathrm{w}$ relacji z personelem medycznym bądź terapeutami. Jednocześnie internet poprzez fora i blogi stanowi dla rodziców miejsce budowania relacji społecznych i otrzymywania wsparcia emocjonalnego, a nawet przyczynia się do konstruowania się tożsamości rodzica dziecka z niepełnosprawnościąa ${ }^{3}$.

Głównymi komponentami analiz sytuacji rodzica dziecka z niepełnosprawnością są kryzys emocjonalny rodziców dzieci z niepełnosprawnością oraz odczuwany przez nich stres.

Kryzys w rodzinie jest przejściową dezorganizacją systemu, wymagającą wprowadzenia zmian w celu przywrócenia stabilności i równowagi wewnętrznej. Zmiany te dotyczą regul, wzorców interakcji, pełnionych ról i struktury rodziny. Rodzina w kryzysie charakteryzuje się szczególnym zbiorem cech niepożądanych ze społecznego punktu widzenia i nie wypełnia swoich funkcji ${ }^{4}$.

Kryzys w tej perspektywie jawi się jako proces dostosowania się rodziny do nowej sytuacji spowodowanej czynnikami zmiany. Siła niepełnosprawności dziecka, jako czynnika determinującego kryzys, jest zależna od innych aspektów funkcjonowania rodziny - jej sytuacji społeczno-ekonomicznej, cech rodziców, ich wzajemnej więzi oraz możliwości adaptacyjnych i przystosowawczych. Kryzys rodziców opisywany jest w większości przypadków rozważań $\mathrm{w}$ tym obszarze tematycznym. Znaczące $\mathrm{w}$ perspektywie radzenia sobie z kryzysem wydają się jednak zachodzące w naszym społeczeństwie zmiany, a także - jak już wskazywałam wyżej - możli-

3 Por.: J. Doroszuk, Sytuacja społeczna rodzin dzieci z niepetnosprawnością. Rekonstrukcja problemowa badań H. Borzyszkowskiej, Uniwersytet Gdański, Gdańsk 2015, praca doktorska niepublikowana, s. 233-270.

4 B. Matyjas, Dzieciństwo w kryzysie: etiologia zjawiska, Wydawnictwo Akademickie „Żak”, Warszawa 2008, s. 107. 
wość wykorzystywania nowych narzędzi normalizacyjnych, w opracowywanych przez rodziców strategiach radzenia sobie.

W literaturze tematu, charakteryzując sytuacje rodziny dziecka z niepełnosprawnością, autorzy często odwołują się do opisu przeżyć emocjonalnych rodziców po uzyskaniu informacji o niepełnosprawności dziecka Andrzeja Twardowskiego. Wskazywał on okresy: szoku bądź wstrząsu emocjonalnego, zwany też okresem krytycznym, kryzysu emocjonalnego, pozornego przystosowania, konstruktywnego przystosowania ${ }^{5}$. Opis procesu oswajania się rodziców z niepełnosprawnością dziecka A. Twardowskiego powstał na podstawie nawiązania autora do badań prowadzonych w latach 70 . przez J.C. Ewert, M.M. Green oraz L. Rosen. Wskazane stany emocjonalne, przeżycia czy tendencje w większości mogą mieć charakter uniwersalny i ponadczasowy. Bardzo ważne we wskazanym opisie jest również ukazanie kształtowania się akceptacji rodzica wobec dziecka z niepełnosprawnością jako procesu, a także wskazanie na możliwość dychotomii między zachowaniem rodzica a jego emocjami (np. okresie tzw. pozornego przystosowania).

Jednak wartym namysłu wydaje się fakt, iż strategie radzenia sobie rodziców z sytuacją kryzysu nie były wówczas (lata 70. XX w.) determinowane o takie czynniki jak m.in. grupy wsparcia, fora internetowe czy szkolenia i kursy dla rodziców dzieci z niepełnosprawnością. Ponadto ze względu na zmiany społeczne i kulturowe, dominację nurtu humanistycznego nad medycznym, a także wzrost tendencji indywidualistycznych (nadających pozytywne znaczenie inności), powstają pytania o aktualny wpływ czynników zewnętrznych na sytuację rodziców dzieci z niepełnosprawnością. Znaczące $\mathrm{w}$ tej perspektywie wydają się również zmiany w układzie strukturalno-funkcjonalnym rodziny ${ }^{6}$. Ponadto współcześnie sam A. Twardowski wskazuje na systemowe ugruntowanie relacji

${ }^{5}$ A. Twardowski, Sytuacja rodzin dzieci niepetnosprawnych, [w:] Dziecko niepetnosprawne w rodzinie, red. I. Obuchowska, WSiP, Warszawa 1991, s. 21-27.

6 Por.: F. Adamski, Rodzina. Wymiar społeczno-kulturowy, Wydawnictwo Uniwersytetu Jagiellońskiego, Kraków 2002, s. 145. 
w rodzinie7. W konsekwencji tworzą się też nowe obszary warte naukowej eksploracji tj. m.in. strategie pozyskiwania przez rodziców pomocy czy sfera komunikacji rodziców z personelem medycznym bądź z innymi specjalistami pracującymi z dzieckiem, a także role odgrywane przez rodziców i ich wpływ na poziom akceptacji niepełnosprawności dziecka.

Rozumienie akceptacji niepełnosprawności dziecka przez rodzica jako liniowego, charakteryzującego się konkretnymi etapami procesu, konfrontowane jest $\mathrm{w}$ literaturze tematu $\mathrm{z}$ przedstawianiem akceptacji dziecka przez rodzica jako procesu cyklicznego, zależnego od czynników zewnętrznych ${ }^{8}$. Postępy rozwojowe dziecka czy otrzymywane wsparcie mogą przyczyniać się do pozytywnych zmian w sytuacji psychospołecznej rodzica i nadawanych jej przez niego znaczeniach. Natomiast kolejne problemy i wyzwania, które napotyka rodzic, jawią się jako dystraktory, negatywnie naznaczające sytuację rodzica oraz powodujące nasilenie odczuwanego przez niego stresu.

Stres rodziców określany jest jako jedna z konsekwencji niepełnosprawności dziecka9 . Dotyczy on zarówno samego faktu niepełnosprawności czy choroby dziecka, jak i jest konsekwencją trudności (związanymi m.in. z funkcjonowaniem potomka, rekcjami otoczenia, czy dodatkowymi obowiązkami), które napotykają rodzice w swojej codzienności. Jako czynnik znaczący dla poziomu stresu odczuwanego przez rodziców wskazywany jest rodzaj zaburzenia $\mathrm{w}$ funkcjonowaniu dziecka ${ }^{10}$. Jako najpodatniejsze na odczuwanie stresu wskazywane są matki dzieci z zaburzeniami ze

7 Por.: A. Twardowski: Wczesne wspomaganie rozwoju dzieci z niepetnosprawnościami w środowisku rodzinnym, Wydawnictwo Naukowe UAM, Poznań 2012.

8 Por.: D. Poston, A.P. Turnbull, J. Park, H. Mannan, J. Marquis, M. Wang, Family quality of life: a qualitative inquiry, "Mental Retardation” 2003, no. 41, s. 313-328.

9 Por.: E. Pisula, Psychologiczne problemy rodziców dzieci z zaburzeniami rozwoju, Wydawnictwo Uniwersytetu Warszawskiego, Warszawa 1998, s. 48-94.

10 Por.: R.M. Hodapp, R.C. Urbano, Adult siblings of individuals with Down syndrome versus with autism. Findings from large scale US survey, "Journal od Intelectual Disability Research" 2007, no. 51, s. 118-129. 
spektrum autyzmu, co może być uwarunkowane zarówno utrudnionym budowaniem relacji matka - dziecko (ze względu na spektrum zaburzeń dziecka autystycznego), jak i reakcjami otoczenia społecznego (niepełnosprawność dziecka jest często niewidoczna, natomiast jego zachowanie odbiega od przyjętych społecznie norm $)^{11}$. Stres matek - zwłaszcza w perspektywie badań Małgorzaty Sekułowicz - wskazywany jest wręcz jako jeden z czynników, obok beznadziejności, frustracji czy izolacji, wpływający na wypalanie się sił rodziców dzieci z niepełnosprawnością ${ }^{12}$.

Rozumienie sytuacji rodzica dziecka z niepełnosprawnością jako naznaczonego odczuwanym stresem oraz radzeniem sobie z kryzysem (bądź kryzysami) w perspektywie sygnalizowanych wyżej zmian $\mathrm{w}$ funkcjonowaniu rodziny skłania mnie do dokonania rekonstrukcji problemowej zjawiska kryzysu rodzica dziecka z niepełnosprawnością. W tym celu wykonałam badanie pilotażowe, którego głównym zamierzeniem było poznanie sytuacji społecznoemocjonalnej rodziców dzieci z niepełnosprawnością w pierwszych latach życia dziecka. Mając na celu dokonanie analizy doświadczeń i przeżyć rodziców, badania zorientowałam w strategii jakościowej ${ }^{13}$. Problem główny stanowiło pytanie o postrzeganie przez rodziców ich sytuacji społeczno-emocjonalnej w perspektywie niepełnosprawności ich dziecka. Problemy szczegółowe zorientowałam wokół takich zjawisk jak: uzyskiwanie diagnozy niepełnosprawności, definiowanie niepełnosprawności przez rodzica, wsparcie otrzymywane przez rodzica, role pełnione przez rodziców, a także wsparcie dziecka w rozwoju.

Mieczysław Łobocki wskazuje, iż „Zrozumienie zjawiska oznacza tyle samo, co zobaczyć je z perspektywy osób, które ono doty-

11 Por.: C.C. Cunningham, Families of children with Down syndrome, "Down Syndrom Research and Practice" 1996, no. 4, s. 87-95.

12 Por.: M. Sekułowicz, Wypalanie się sił rodziców dzieci z niepetnosprawnością, Wydawnictwo Naukowe Dolnośląskiej Szkoły Wyższej, Wrocław 2013.

13 Por.: M. Szymański, O znaczeniu badań jakościowych nad wartościami, [w:] Z badań nad wartościami w pedagogice, red. W. Furmanek, Zakład Dydaktyki, Techniki i Informatyki Uniwersytetu Rzeszowskiego, Rzeszów 2006, s. 51. 
czy, czyli odtworzyć subiektywne nurty znaczeniowe mu przypisane"14. Biorąc pod uwage jednostkowy oraz unikatowy wymiar doświadczeń w obszarze rodzicielstwa naznaczonego niepełnosprawnością, skuteczną drogą do poznania perspektywy rodzica wydał mi się wywiad jakościowy, którego celem jest - jak wskazuje Steinar Kvale - „[...] uzyskanie interpretacji opisu świata przeżyć osoby udzielającej wywiadu"15.

Wywiady zostały przeprowadzone przez studentki II roku magisterskich studiów uzupełniających na kierunku Pedagogika Specjalna - Wczesne Wspomaganie Rozwoju Dziecka na Uniwersytecie Gdańskim w ramach prowadzonego przeze mnie przedmiotu praca $\mathrm{z}$ rodziną małego dziecka. Przed rozpoczęciem wywiadów wraz ze studentkami ustaliłam kwestie kluczowe w obszarze metodologii badania oraz pytania naprowadzające i ukierunkowujące wywiad na poznanie odpowiedzi na postawione problemy badawcze. Wywiady analizowałam samodzielnie. Omawiałam je jednak także ze studentami w ramach zajęć akademickich, co umożliwiło mi poznanie interpretacji pedagogów specjalnych rozpoczynających swą drogę zawodową i również współpracę z rodzicami.

Próbę badawczą stanowiło 20 rodziców (19 matek i 1 ojciec), których dzieci korzystają z wczesnego wspomagania rozwoju. Badani mają dziecko (bądź dzieci) z niepełnosprawnością ruchową (5 rodziców), intelektualną (2), sensoryczną (2) lub sprzężoną (4) bądź występują u nich zaburzenia ze spektrum autyzmu (7). Wywiady różniły się objętością i szczegółowością, ze względu na różne sposoby narracji rodziców, a także ze względu na czas, który mogli oni poświęcić na udzielenie wywiadu. Materiał badawczy łącznie obejmuje kilkadziesiąt stron transkrypcji.

Proces analizy materiału obejmował:

- czytanie materiału badawczego jednoczesnym zaznaczaniem fragmentów znaczących pod kątem pytań badawczych,

${ }_{14}$ M. Łobocki, Wprowadzenie do metodologii badań pedagogicznych, Oficyna Wydawnicza „Impuls”, Kraków 1999, s. 87.

$15 \mathrm{~S}$. Kvale, InterViews. Wprowadzenie do jakościowego wywiadu badawczego, Wydawnictwo Uniwersyteckie „Trans Humana”, Białystok 2009, s. 17. 
- czytanie zaznaczonych fragmentów, podkreślanie słów czy zdań kluczowych, tworzenie danych kategorii na ich podstawie,

- przyporządkowanie wybranych fragmentów do pytań badawczych,

- syntezę danych problemów badawczych według tematyki zagadnień,

- analizę i weryfikację wyznaczonych kategorii.

Kategorie, które wyznaczyłam:

1. Rodzic świadomy i wymagający.

2. Sztywny podział ról w rodzinie dziecka z niepełnosprawnością.

3. Rodzic „w zadaniu” - koncentracja rodzica na radzeniu sobie $\mathrm{z}$ trudnościami.

4. Internet jako ważne źródło wiedzy.

5. Lęk związany z przyszłością dziecka.

Dokonując ich opisu, podam przykłady z narracji rodziców, a także postaram się wskazać obszary, które wydają mi się znaczące dla dalszych analiz i naukowych eksploracji.

\section{Ad. 1. Rodzic świadomy i wymagajacy}

Zdecydowana większość badanych rodziców bardzo precyzyjnie określała swoje oczekiwania względem terapii i edukacji dziecka. Wypowiedzi rodziców dotyczyły zarówno tego, jaką metodą powinno być prowadzone dziecko, jakie ćwiczenia powinien wybierać terapeuta i jaką postawę prezentować, jak i rodzajów i form wsparcia, które dziecku ze strony placówek terapeutycznych i edukacyjnych się należą.

Przykładowe wypowiedzi rodziców:

Mama Pauliny16: Wygląa to tak jak wyglada, mówi się o tym, że szkoty powinny realizować wszystko, co poradnie zapisza. A z drugiej strony jest ustawa, jeżeli chodzi o dyrektora - dostaje [subwencję przyp. red.]. Paulina ma bardzo wysoka subwencje, bo ona ma niepetnosprawność sprzężona, a dyrektor dostaje na oddziat, czyli na dana

16 Ze względu na poszanowanie prywatności, imiona dzieci zostały zmienione. 
klase, finanse na 10 godzin tygodniowo. Czyli jak jest pięcioro dzieci, no to dwa zajęcia, a jak Paulina powinna mieć integracje sensoryczna, logopede, rehabilitacje, terapię wzroku, to już mamy cztery, a jest pięcioro dzieci. No więc to jest tak właśnie: dwójka dzieci na rehabilitację, gdzie ona powinna mieć ćwiczenia tylko i wyłacznie. że tak powiem, skupiajace bardzo precyzyjnie na wykonywanym zajęciu typu rehabilitacja, że ona, nie wiem, będzie robić przysiady, nie do końca je robiąc czy nie do końca dotykając pupa podtogi, tylko bardziej pod katem prostym w kolanach, ona ma nawykowe podwinięcie rzepek, więc te rzepki potrafia zrobić dziury w kolanach, rzepki sa z boku, bo takie ma stawy wiotkie. Też pilotowane przez rehabilitanta, ona tego nie powinna robić samodzielnie. Wiec rehabilitant wybiera ćwiczenia takie, że tak powiem: pierdu pierdu, bo taka jest rehabilitacja w szkole. Mówię: poradnie mówia jedno, ustawy mówią drugie, dyrektorzy się motaja, a my szukamy po bokach. I tak to wyglada w rzeczywistości ${ }^{17}$.

Tata Jasia: Żeby być dobrym terapeuta, trzeba wczuć się w rolę dziecka. Po prostu jak coś nie chce robić, to nie musi tego dziecko robić. Zajęcia musza być atrakcyjne, wtedy dziecko fajnie uczestniczy. Jak nie będa atrakcyjne, to nie będa wspótpracować.

Mama Bartka: Niestety, yyy, to byt dość dtugi proces znalezienia przedszkola, które by było integracyjne, które miałoby terapię taka, jakg ja chce, więc szukałam i szukałam.

Charakterystyczne w tym aspekcie były też inne wypowiedzi badanych dotyczące zmian placówek, terapii bądź terapeutów niespełniających wymagań rodziców.

Przyczynę takich świadomej i wymagającej postawy rodzica upatruję zarówno w małej drożności systemu na poziomie wczesnego wspomagania rozwoju dziecka oraz w lepszym dostępie do wiedzy, nawet tej o charakterze specjalistycznym. Brak systemowego wsparcia (choćby informacyjnego) rodzica w obszarze leczenia

17 Forma wszystkich cytowanych wypowiedzi badanych - oryginalna, wraz z błędami językowymi - przyp. red. 
i terapii dziecka stanowi o przeniesieniu na niego odpowiedzialności za rozwój jego dziecka z niepełnosprawnością. Natomiast powszechny dostęp do internetu, literatury oraz szkoleń i kursów sprawia, iż rodzic dziecka z niepełnosprawnością niejednokrotnie ma - w danym zakresie, dotyczącym specyfiki funkcjonowania i potrzeb jego potomka - wiedzę większą niż pedagog czy terapeuta, zwłaszcza ten na początku swojej drogi zawodowej.

Wskazane zachowania, postawy czy potrzeby badanych wydają się znaczące $\mathrm{w}$ perspektywie współpracy rodziców $\mathrm{z}$ pedagogiem, terapeutą czy placówką edukacyjną bądź terapeutyczną. Rodzic posiadający wiedzę oraz pewny swoich przekonań dotyczących wspomagania rozwoju dziecka stanowi wyzwanie dla osób pracujących z jego dzieckiem. Ważne w tym aspekcie wydają się więc rozważania i analizy dotyczące jakości i form współpracy z rodzicami, a także miejsca i roli rodzica $\mathrm{w}$ zespole interdyscyplinarnym pracującym z dzieckiem z niepełnosprawnością.

\section{Ad. 2. Sztywny podział ról w rodzinie dziecka z niepełnosprawnościa}

Podział ról w rodzinie posiadającej dziecko, na osobę opiekującą się nim i utrzymującą rodzinę poprzez pracę zarobkową, ma tradycyjny charakter, lecz współcześnie nadal występuje w wielu rodzinach, niezależnie od poziomu sprawności dziecka. Analizując wypowiedzi badanych matek, zwróciłam jednak uwagę na czynniki wyróżniające ich sytuację. Mianowicie obciążenie badanych jest zdecydowanie większe. Czynności opiekuńcze są niejednokrotnie zmaksymalizowane ze względu na obniżony poziom samodzielności dziecka bądź jego potrzeby (np. cewnikowanie). Dodatkowo badane wskazywały m.in. na konieczność zawożenia dziecka na terapie, kontynuowania terapii w domu, organizowanie dofinansowania oraz zakupu, a także dbania o sprzęt rehabilitacyjny. Znaczący jest również fakt, iż czas pozostania rodzica dziecka $z$ niepełnosprawnością $\mathrm{w}$ domu nie jest stanem przejściowym (jak czas urlopu macierzyńskiego czy wychowawczego) tylko może trwać wiele lat, a nawet całe życie dziecka. Natomiast wzmożone koszty wspierania rozwoju i funkcjonowania dziecka $z$ niepełnosprawno- 
ścią implikują zaangażowanie drugiego rodzica w pracę zarobkową. Sztywny podział ról w rodzinie dziecka z niepełnosprawnością oraz negatywne emocje i napięcie, które może on powodować pomiędzy rodzicami, obrazuje m.in. wypowiedź mamy Julka o relacji z mężem:

Były kłótnie między nami. Był brak porozumienia. Ja mu zazdrościłam, $\dot{z}$ e on idzie do pracy, wychodzi. Ja uważałam wówczas, że jego życie się kompletnie nie zmieniło, że on ma super. On idzie do pracy, idzie do ludzi i robi to, co zawsze. A moje życie, przewrócito się do góry nogami, nie... Bo musiatam wszystko uporządkować, musiatam zrezygnować, nie wiem, z jakichś swoich dni wolnych, myśli o sobie. No o czymkolwiek. Nawet o zwyktych zakupach, bo moje myśli to była tylko przychodnia, szpital, poradnia, rehabilitacja, recepty $i$ opieka nad chorym dzieckiem. Myślatam, że oszaleję, i to też rzutowało na to, że ja się z Krzyśkiem kłóciłam.

Ważne w tym aspekcie wydaje się również zjawisko, które nazwałabym systemowym uwarunkowaniem sztywnego podziału ról, na które wskazuje m.in. mama Michała:

A! I jeszcze co by się bardzo przydało, to się wiąże i z finansami, i z organizacją, żeby ogólnie można było łączyć świadczenie z praca zarobkowa. Bo teraz albo pracujesz albo kompletnie nie pracujesz i dostajesz świadczenia. Na świadczeniu nie możesz sobie nic dorobić $i$ praca $w$ takim przypadku często jest wybawieniem. W tym sensie, że idac do pracy, zapominasz o tym, co zostawiasz w domu.

Oprócz specyfiki funkcjonowania dziecka, które może potrzebować całodobowej opieki i obecności rodzica, uwarunkowania otrzymywania świadczeń finansowych stanowią ważny czynnik implikujący sztywny podział ról w rodzinie. Jego konsekwencje w obszarze sytuacji społeczno-emocjonalnej matek (które zazwyczaj zostają w domu z dzieckiem), relacji wewnątrzrodzinnych, a nawet w aspekcie akceptacji niepełnosprawności dziecka przez rodziców, określam jako ważne dla dalszych analiz i poszukiwań naukowych, 
a także dla rozważań dotyczących optymalizacji wsparcia systemowego.

Ad. 3. Rodzic „w zadaniu” - koncentracja rodzica na radzeniu sobie z trudnościami

Mama Pauliny: Natomiast to skupienie na Paulince jest ze względów zdrowotnych strasznie mocno. Ona ma bardzo dużo problemów z żywieniem i ja nieustannie siedze w kuchni. Paulinka jeść może bardzo niewiele. Wczoraj tylko placki dla Pauliny, które miała na wczoraj i dzisiaj, kilka ich zamroziłam, a czas, który spędziłam na te placuszki to 2,5 godziny. [...] My staramy się żyć normalnie w nienormalnych warunkach.

Powyższy cytat stanowi jedną z wielu wypowiedzi rodziców dotyczących dodatkowych (często mocno obciążających rodzica) obowiązków, które wynikają ze specyfiki funkcjonowania i potrzeb dziecka z niepełnosprawnością. Znaczna większość badanych opowiadała o dodatkowych czynnościach pielęgnacyjnych, przygotowywaniu pomocy dydaktycznych, wykonywaniu zaleceń terapeutów bądź włączaniu terapii w życie codzienne, organizowaniu sprzętu wspomagającego funkcjonowanie dziecka, pobytu w szpitalach, ośrodkach terapeutycznych czy na turnusach rehabilitacyjnych. Dzień badanych niejednokrotnie od świtu do zmierzchu wypełniony jest zadaniami, które muszą bądź czują się w obowiązku wykonać.

Ważne w tym obszarze jest również znaczenie, jakie rodzice nadają terapii w procesie wspomagania rozwoju dziecka. Większość dzieci badanych uczęszcza w ciągu tygodnia na wiele różnych terapii, które niemal całkowicie wypełniają ich czas wolny (oraz wypełniają czas rodzica, który uczestniczy w terapii bądź czeka na dziecko). Przykładem może być tu fragment wypowiedzi mamy Martyny, opisującej swój dzień:

Krótkie szybkie śniadanie i na 8.00 jedziemy do przedszkola integracyjnego. Tam Martyna zostaje przez sześć godzin. O 14.00 odbieram ja. 
z przedszkola i jedziemy na zajęcia. Zajęcia sa różne, każdego dnia inne $i$ gdzie indziej. Po powrocie do domu pracujemy jeszcze w domu, a około 18.00 Martyna idzie się kapać. [...] Po pluskaniu, gdzieś około 20.00, usypia i czasem śpi po osiem godzin, czasem cztery, u nas jest to naprawdę różnie. I tak wygląda nasz typowy dzień. W sobotę dodatkowo jeździmy jeszcze na zajęcia do Bydgoszczy.

Odwołując się do wskazanych wcześniej badań M. Sekułowicz dotyczących wypalania się sił matek dzieci z niepełnosprawnościąi ${ }^{18}$, podkreślam, jak duże znaczenie dla emocjonalnego funkcjonowania rodzica może mieć jego stan psychofizyczny, brak odpoczynku, czasu dla siebie, możliwości zbudowania dystansu do odgrywanej roli. W wypowiedziach badanych widoczne było również napięcie pomiędzy odczuwanym zmęczeniem i obciążeniem a takimi kategoriami jak akceptacja "trudnych” zachowań dziecka, współpraca z terapeutami czy budowanie relacji społecznych. Istotnym w tym obszarze wydaje się namysł nad optymalnym wsparciem dziecka z niepełnosprawnością przy jednoczesnym odciążeniu rodzica. W perspektywie analiz materiału badawczego wydaje się to konieczne dla przepracowania przez rodzica tematu niepełnosprawności dziecka oraz dla wzmocnienia jego relacji $\mathrm{z}$ dzieckiem.

\section{Ad. 4. Internet jako ważne źródło wiedzy}

W swoich wypowiedziach wszyscy badani podkreślali znaczenie internetu jako ważnego źródła wiedzy zarówno dotyczącej schorzenia,czy niepełnosprawności dziecka, jak i możliwości leczenia czy terapii oraz pozyskiwania wsparcia systemowego. Znaczące jednak w perspektywie moich wcześniejszych badań wydaje się, iż żadne z rodziców nie wspomniało o internecie jako „miejscu” otrzymywania wsparcia społecznego i emocjonalnego. Blogi czy fora internetowe stanowią więc narzędzia normalizacyjne, których $\mathrm{w}$ tym aspekcie badani nie wykorzystują, mimo iż znaczna więk-

18 Por.: M. Sekułowicz, op. cit. 
szość w swych wypowiedziach określa się jako samotnych czy odizolowanych od otoczenia społecznego (także przez brak czasu). $\mathrm{W}$ aspekcie tym powstają pytania o budowanie społecznych relacji przez rodziców małych dzieci z niepełnosprawnością i miejsce internetu w obszarze ich aktywności społecznych.

\section{Ad. 5. Obnażenie trudności w zaakceptowaniu niepełnosprawności} potomka w procesie wyznaczania celów wspierania rozwoju dziecka

Podczas analizy wywiadów okazało się, że odpowiedzenie na pytanie dotyczące przyszłości dziecka sprawiało prawie połowie badanych dużą trudność. Obserwowalna jest również znaczna dychotomia $\mathrm{w}$ ładunku emocjonalnym wypowiedzi dotyczących codziennego funkcjonowania, terapii czy relacji z dzieckiem, a tych dotyczących stawiania celów w wspomaganiu dziecka, a także tego, jak rodzic wyobraża sobie swojego potomka za kilka lat, co obrazuje m.in. wypowiedź mamy Martyny:

Kompletnie nie wyobrażam sobie, że Martyna nie będzie mówić... Cały czas ciężko mi pogodzić się z ta myśla, ̇̇e Martyna jest niepetnosprawna intelektualnie... Dzięki naszej pracy Martyna zaczęła chodzić, gdy miała dwa latka. Sama nie wiem, jakby to by wygladało w dniu dzisiejszym, gdybym nad tym nie pracowata, pewnie do dziś by nie chodziła. Cały czas walczymy, nie poddajemy się. Oby było tylko lepiej, a czas pokaże, co będzie dalej. Szczerze mówią, mam czasem już wszystkiego dość... Jestem tak naprawdę z tym wszystkim sama, lecz walcze, walczę aby Martyna miała lepsza przyszłość. Może kiedyś, pewnego dnia, stanie w moim pokoju, poogladamy razem stare zdjęcia, jak to było kiedyś, a jak jest teraz... Porozmawiamy o tym, co wywalczyłyśmy, $w$ tych trudnych chwilach. Może mi kiedyś za to podziękuje i tylko w mojej głowie ciagle siedzi, że kiedyś powie do mnie KOCHAM CIĘ MAMO!

Pytanie dotyczące przyszłości dziecka konfrontowało rodziców z ich własnym lękiem, żalem oraz nadzieją. Większość badanych wydaje się dość mocno skoncentrowana na teraźniejszości, co de- 
terminowane jest również przez duże obciążenie, na które wskazywałam powyżej. W tej perspektywie "rodzic w zadaniu”, to rodzic, który nie ma możliwości i czasu na przepracowanie tematu niepełnosprawności swojego dziecka, a w konsekwencji jej zaakceptowanie. Utrudniająca - wbrew pozorom - dla poradzenia sobie z negatywnymi emocjami może być postawa, która jest od rodziców często oczekiwana przez środowisko terapeutyczne i edukacyjne, a mianowicie mocne zaangażowanie badanych $\mathrm{w}$ terapie, stawianie celów, kompensowanie, wyrównywanie i usprawnianie.

Uwarunkowania procesu akceptacji dziecka i jego niepełnosprawności przez rodzica stanowią obszar dociekań naukowych, który zamierzam dalej eksplorować. Omawiane badanie pilotażowe wskazuje na pulsowanie kategorii rodzicielstwa i macierzyństwa naznaczonego niepełnosprawnością, w takich obszarach jak akceptacja niepełnosprawności czy wspomaganie rozwoju dziecka.

\section{Podsumowanie}

Podsumowując przeprowadzone badania pilotażowe oraz moje rozważania $\mathrm{w}$ temacie kryzysu emocjonalnego rodzica dziecka z niepełnosprawnością, chciałabym podkreślić, jak ważny i złożony jest proces konstruowania się rodzicielstwa $\mathrm{w}$ obliczu niepełnosprawności dziecka w okresie jego wczesnego dzieciństwa. Swoiście nowe postawy rodziców dzieci z niepełnosprawnością, ich większa wiedza i świadomość oczekiwań wobec terapii i terapeutów czy skoncentrowanie na procesie rehabilitacji dziecka nie wykluczają trudności i obciążeń, które naznaczają bycie rodzicem dziecka z niepełnosprawnością. Sytuacja społeczno-emocjonalna badanych rodziców, której zarys starałam się zaprezentować, skłania do dalszych refleksji i badań dotyczących czynników implikujących radzenie sobie rodziców z emocjami i sytuacjami trudnymi (kryzysowymi), a także ukierunkowuje na poznawanie momentów "przejścia” pomiędzy kolejnymi etapami tworzenia się tożsamości rodzica dziecka z niepełnosprawnością. Zrozumienie motywów postępo- 
wania rodziców przez pedagoga specjalnego może przyczynić się natomiast do rozszerzenia obszaru jego rozważań nad wsparciem oferowanym rodzinie dziecka z niepełnosprawnością.

\section{Bibliografia}

Adamski F., Rodzina. Wymiar spoteczno-kulturowy, Wydawnictwo Uniwersytetu Jagiellońskiego, Kraków 2002.

Borzyszkowska H., Izolacja społeczna rodzin mających dziecko upośledzone umystowo w stopniu lekkim, Wydawnictwo Uniwersytetu Gdańskiego, Gdańsk 1997.

Cunningham C.C., Families of children with Down syndrome, "Down Syndrom Research and Practice" 1996, no. 4.

Doroszuk J., Sytuacja społeczna rodzin dzieci z niepetnosprawnością. Rekonstrukcja problemowa badań H. Borzyszkowskiej, Uniwersytet Gdański, praca doktorska niepublikowana, 2015.

Hodapp R.M., Urbano R.C., Adult siblings of individuals with Down syndrome versus with autism. Findings from large scale US survey, "Journal od Intelectual Disability Research" 2007, no. 51.

Krause A., Wspótczesne paradygmaty pedagogiki specjalnej, Oficyna Wydawnicza „Impuls", Kraków 2011.

Kvale S., InterViews. Wprowadzenie do jakościowego wywiadu badawczego, Wydawnictwo Uniwersyteckie „Trans Humana”, Białystok 2009.

Łobocki M., Wprowadzenie do metodologii badań pedagogicznych, Oficyna Wydawnicza „Impuls”, Kraków 1999.

Matyjas B., Dzieciństwo w kryzysie: etiologia zjawiska, Wydawnictwo Akademickie "Żak", Warszawa 2008.

Pisula E., Psychologiczne problemy rodziców dzieci z zaburzeniami rozzoju, Wydawnictwo Uniwersytetu Warszawskiego, Warszawa 1998.

Poston D., Turnbull A.P., Park J., Mannan H., Marquis J., Wang M., Family quality of life: a qualitative inquiry. "Mental Retardation" 2003, no. 41.

Sekułowicz M., Wypalanie się sił rodziców dzieci z niepetnosprawnościa, Wydawnictwo Naukowe Dolnośląskiej Szkoły Wyższej, Wrocław 2013.

Szymański M., O znaczeniu badań jakościowych nad wartościami, [w:] Z badań nad wartościami w pedagogice, red. W. Furmanek, Zakład Dydaktyki, Techniki i Informatyki Uniwersytetu Rzeszowskiego, Rzeszów 2006.

Twardowski A., Sytuacja rodzin dzieci niepełnosprawnych, [w:] Dziecko niepetnosprawne w rodzinie, red. I. Obuchowska, WSiP, Warszawa 1991.

Twardowski A., Wczesne wspomaganie rozwoju dzieci z niepetnosprawnościami w środowisku rodzinnym, Wydawnictwo Naukowe UAM, Poznań 2012. 